\title{
Traineeprogram etablerer heltidsstillinger og sikrer sykepleiefaglig kompetanse
}

Ved SUS ansettes traineesykepleiere i full stilling og rullerer mellom kirurgisk sengepost og poliklinikk. De får bred erfaring, tett oppfølging og en passende stilling de kan søke på etter endt program.

\section{Anne Marie Lunde Husebø}

Førsteamanuensis

Avdeling for folkehelse, Det helsevitenskapelige fakultet, Universitetet i Stavanger og

Kirurgisk klinikk, Stavanger Universitetssjukehus

\section{Anne Ree Jensen}

Klinikksjef

Kirurgisk klinikk, Stavanger universitetssjukehus

\section{Bente Rossavik}

Fagsjef for sykepleietjenesten

Kirurgisk divisjon, Stavanger universitetssjukehus

\section{Sissel Eikeland Husebø}

\section{Professor}

Avdeling for kvalitet og helseteknologi, Det helsevitenskapelige fakultet, Universitetet i Stavanger og Kirurgisk klinikk, Stavanger universitetssjukehus 


\section{Hovedbudskap}

Et traineeprogram for nyutdannede sykepleiere i sykehus kan gi dem relevant og bred opplæring samt bidra til høyere trivsel og kollegialt fellesskap. Veiledning og samtalegrupper gir rom for refleksjon i trygge omgivelser. Sykepleierne opplevde at de ble verdsatt, fikk økt sykepleiefaglig og organisatorisk kunnskap og kompetanse i tillegg til bedre arbeidsvilkår. For flere sykepleiere kan deltakelse i traineeprogram være starten på videreutdanning og spesialisering.

I spesialisthelsetjenesten er det utfordrende å rekruttere kvalifiserte fagfolk til sykepleierstillinger (1, 2). Nyutdannede sykepleiere har behov for veiledning og støtte i overgangen mellom utdanning og klinisk praksis og bør derfor tilbys en form for mentorordning (3).

Mentorordninger kan redusere stress og bidra til høyere selvtillit og kompetanse hos nyutdannede sykepleiere $(4,5)$. Stavanger universitetssjukehus (SUS) satte i gang et traineeprogram i 2013 som skulle bidra til å rekruttere og beholde nyutdannede sykepleiere ved kirurgiske sengeposter.

Målsettingen med programmet er å etablere heltidsstillinger for sykepleiere og sikre sykepleiefaglig kompetanse av høy kvalitet som dekker den kirurgiske pasientens behov for sykepleie (6). Artikkelen beskriver evalueringen av traineeprogrammet.

\section{Beskrivelse av traineeprogrammet}

Stavanger universitetssjukehus er organisert i sju klinikker og har cirka 8000 ansatte - av dem er cirka 2500 sykepleiere. Sykehuset er inndelt i kirurgisk og medisinsk flytsone, og sengepostene i flytsonen samarbeider om den daglige pasientflyten inn i sykehuset.

Traineeprogrammet i kirurgisk flytsone ved SUS er et samarbeid mellom tre medisinske og tretten kirurgiske poster og poliklinikker ved Kirurgisk klinikk, Klinikk for hode, hals og rehabilitering samt Ortopedisk klinikk. 
Kirurgisk flytsone har cirka åtte traineesykepleiere ansatt til enhver tid. Sykepleierne som ansettes, er nyutdannede med inntil ett års erfaring. Traineeprogrammet går over to år, og det ansettes inntil fem sykepleiere hver vår.

Sykepleierne som deltar i traineeprogrammet, er omtrent fire måneder på seks sengeposter eller poliklinikker i løpet av programmet. Det tilstrebes at sykepleierne får en bredest mulig erfaring. De får opplæring som nyansatt ved SUS samt to ukers opplæring når de skifter sengepost eller poliklinikk.

I programmet er det sykepleiefaglig veiledning med NSF-godkjente veiledere hver 14. dag, der traineesykepleierne deltar sammen med sykepleiere som er ansatt $i$ «vanlige» stillinger. Gruppene har faste deltakere i to år.

Det inngår også faste samtaler hver sjette uke med fagsjefen for sykepleie og klinikksjefen, som begge er sykepleiere. I samtalene vektlegger de forbedring av sykepleietjenesten i klinikkene samt arbeidsrelaterte områder med behov for $\varnothing \mathrm{kt}$ kompetanse.

\section{«Alle traineesykepleierne blir ansatt i 100 prosent fast stilling.»}

Traineesykepleierne får mulighet til en individuell samtale med fagsjefen for sykepleie, der de kan ta opp saker som ikke egner seg i plenum. Det som kommer frem i samtaler og veiledningsgrupper, forblir i gruppen.

Alle traineesykepleierne blir ansatt i 100 prosent fast stilling. Det er ikke stillingshjemler til disse, men de settes inn i ledige stillinger som man ellers måtte leid inn vikarer til, som ved langtidssykemeldinger, svangerskapspermisjoner og liknende. 
Etter endt toårs traineeprogram forplikter klinikkene som samarbeider om ordningen, å finne ledige sykepleierstillinger som traineesykepleierne kan s $\varnothing \mathrm{ke}$ på, ved en sengepost eller poliklinikk. Til dags dato har alle traineesykepleierne blitt ansatt i ledige stillinger der de har ønsket å fortsette arbeidsforholdet.

Siden 2013 har SUS hvert år lyst ut toårige traineestillinger for sykepleiere ved kirurgiske sengeposter og poliklinikker, med påfølgende ansettelse.

\section{Metode}

Vi ønsket å unders $\varnothing$ ke deltakernes erfaringer med traineeprogrammet og kartlegge forbedringsområder. I den forbindelsen sendte vi ut et elektronisk evalueringsskjema til sykepleierne som hadde deltatt $\mathrm{i}$ traineeprogrammet i perioden 2013 til 2019.

I tidsrommet 2013 til 2019 deltok 21 sykepleiere i programmet. Av disse fullførte 19 sykepleiere. To fullførte 50 prosent, men sluttet deretter fordi de flyttet til en annen landsdel.

Svarene i de returnerte evalueringsskjemaene ble kodet, kondensert og kategorisert i fire temaer.

\section{Deltakere og etikk}

Samtlige deltakere i programmet ble invitert til å delta i den elektroniske evalueringen. Inklusjonskriteriene var offentlig godkjente sykepleiere som hadde fullført mer enn 50 prosent av traineeprogrammet. Prosjektet ble godkjent av Personvernombudet ved SUS og av aktuelle klinikksjefer.

Alle inviterte programdeltakere mottok en e-post med skriftlig prosjektinformasjon, samtykkeskjema og evalueringsskjema. Ti programdeltakere returnerte utfylt evalueringsskjema og ble inkludert i unders $\varnothing$ kelsen. 


\section{Evalueringsskjemaet}

Vi benyttet et elektronisk evalueringsskjema

(Corporate Surveyer-programvare) som

datainnsamlingsmetode. Vi utviklet spørsmålene ut fra

hensikten med prosjektet, overordnet målsetting og

innhold i traineeprogrammet.

I første delen av evalueringsskjemaet inngår

bakgrunnsopplysninger som alder, kjønn og motivasjon

for å s $\varnothing$ ke traineestilling ved SUS. Andre delen

inneholder sju åpne spørsmål relatert til

traineeprogrammets innhold (tabell 1).

Tabell 1. Spørsmål i evalueringsskjemaet

1. Kan du beskrive på hvilken måte traineeprogrammet ved SUS bidro til, eventuelt ikke bidro til, økt sykepleiefaglig kompetanse?

2. Kan du beskrive på hvilken måte veiledningen $\mathrm{i}$ traineeprogrammet bidro til, eventuelt ikke bidro til, at du fikk hevet din sykepleiefaglige kompetanse?

3. Kan du beskrive på hvilken måte samtalene sammen med hele traineegruppen bidro til, eventuelt ikke bidro til, utbytte av traineeprogrammet?

4. Kan du beskrive på hvilken måte varierende arbeidspraksis ved ulike avdelinger bidro til, eventuelt ikke bidro til, at du fikk hevet din sykepleiefaglige kompetanse?

5. Hva er din erfaring med å delta i traineeprogrammet?

6. Hva var bra med traineeprogrammet?

7. Hva kan forbedres med traineeprogrammet?

\section{Resultater}

Kjennetegn ved deltakerne er beskrevet i tabell 2. 
Tabell 2. Kjennetegn ved deltakerne

\begin{tabular}{ll}
\hline Kjennetegn & Antall \\
\hline $\begin{array}{l}\text { Kjønn } \\
\bullet \text { Kvinner }\end{array}$ & 8 \\
\hline $\begin{array}{l}\text { Alder (år) } \\
\text { Hvorfor traineestilling ble søkt } \\
\bullet \text { Få fast 100-prosentstilling, få variert praksis eller for å utvikle sykepleierkompetansen }\end{array}$ & 2 \\
$\quad$ av innholdet i programmet & $24-38$ \\
\hline $\begin{array}{l}\text { Arbeider fortsatt i } 100 \text { prosent fast stilling etter at programmet var fullført } \\
\text { Ikke startet på videre- eller masterutdanning etter fullført program }\end{array}$ & $4-6$ \\
\hline Har arbeidet ved SUS mindre enn ett år & 9 \\
\hline Jobber fortsatt som sykepleier ved Sus & 7 \\
\hline
\end{tabular}

Vi identifiserte følgende fire temaer: 1) erfaringer med programmets innhold og struktur, 2) mulighet og rom for refleksjon, 3) utvikling av sykepleiefaglig kompetanse, og 4) suksessfaktorer og forbedringsområder.

\section{Erfaringer med programmets innhold og struktur}

Temaet tar for seg programmets oppbygging, innhold, sammensetning av traineegruppen og den enkeltes påvirkningsmulighet. De fleste deltakerne uttrykte at de fikk god mottakelse og opplæring når de byttet arbeidssted. De ga også uttrykk for at samtalene hver sjette uke ga dem praktisk informasjon, men at de også var viktige for sykepleiernes tilhørighet på postene:

«God oppfølging gjennom traineesamtalene gjorde at man følte at man hørte til et sted, selv om man byttet fra avdeling til avdeling.»

Deltakerne erfarte at interessante praksiscaser ble tatt opp i veiledningen, og at det skapte gode diskusjoner om aktuelle temaer. Traineesykepleierne var tilfredse med at de fikk sette opp prioriteringsønsker for sengeposter, og at disse ble sett i sammenheng med prinsippet om å gi traineesykepleierne bredest mulig erfaring. 


\section{Mulighet og rom for refleksjon}

Dette temaet handler om deltakernes beskrivelser av hvordan programmets veiledning og samtaler ga dem mulighet og rom for diskusjon og refleksjon over faglige og etiske problemstillinger. Veiledningen og samtalene bidro dermed til $\varnothing \mathrm{kt}$ sykepleiefaglig kompetanse og erfaringsoverføring. Deltakerne mente at diskusjoner, refleksjoner og deling av erfaringer ga dem nye perspektiver på utøvelsen av sykepleie:

«Den [veiledningen] bidro med å få en unik mulighet til å drøfte og reflektere over situasjoner der du kanskje satt med en viss tanke om hvordan noe skulle være, men gjennom veiledning fikk man tilførsel av andres tanker og drøftinger, som igjen førte til at man fikk bredere blikk og forståelse.»

Gjennom veiledning og refleksjon sammen med andre sykepleiere og deltakere i programmet opplevde traineesykepleierne at de fikk støtte fra andre. De kunne ta opp saker på en trygg arena og utvikle seg faglig og personlig.

\section{Utvikling av sykepleiefaglig kompetanse}

I dette temaet beskrev deltakerne hvordan traineeprogrammet hadde påvirket deres profesjonelle kompetanse ved at de fikk økt kunnskap og kompetanse innen ulike sykepleiefaglige områder.

Flere mente at variert praksis ved ulike sengeposter og poliklinikker bidro til mer kunnskap om diagnoser, behandling og sykepleieprosedyrer. De fikk mulighet til å observere og erfare andre måter å ut øve sykepleie på gjennom rullering mellom poster og samarbeid med nye kolleger.

Det å få arbeidserfaring ved ulike sengeposter og poliklinikker bidro til at de utviklet en bredere sykepleiefaglig kunnskap, av noen forklart som en generell kompetanse, slik som denne deltakeren uttrykte det: 
«Økt kompetanse ved at man etter traineeforløpet kan 'litt om mye, men ikke mye om noe', sammenliknet med sykepleiere som hadde jobbet på samme avdeling i to år.»

\section{«Det å få arbeidserfaring ved ulike sengeposter og poliklinikker bidro til at de utviklet en bredere sykepleiefaglig kunnskap.»}

Sykepleierne uttrykte at de tok med nyvunnen kompetanse videre og delte med kolleger. De opplevde at kompetansen deres ble lagt merke til og satt pris på, og det bidro til at de kunne hjelpe andre avdelinger. Variasjon i praksis krevde at de i større grad måtte holde seg faglig oppdatert og hente frem kunnskaper som hadde ligget «ubrukt».

Traineeprogrammet styrket sykepleiernes organisatoriske kompetanse ved at de fikk erfaringer om og innsikt i måter å administrere sykepleie på, fra ulike sengeposter og poliklinikker. Det ga dem et mer helhetlig bilde av sykehuset, og de fikk $\varnothing \mathrm{kt}$ innsikt i og forståelse av klinikkens organisatoriske oppbygning og funksjon, arbeidsmiljømessige utfordringer og nye arbeidsrutiner, som en av deltakerne uttrykte det:

«Fikk innblikk i hvordan de forskjellige avdelingene fungerte, utvekslet erfaringer og diskuterte viktige temaer som er relevante for praksis, [og fikk] innblikk i situasjonen på hele [syke]huset.»

Sykepleierne mente at $\varnothing k t$ kompetanse etter å ha deltatt i traineeprogrammet hadde gitt dem en større trygghet som sykepleier og arbeidstaker. En av deltakerne skrev følgende:

«Jeg oppnådde det jeg ønsket i programmet, jeg fikk fast stilling samt bredere kompetanse og godt innblikk i forskjellige typer kirurgiske avdelinger.» 


\section{Suksessfaktorer og forbedringsområder}

Blant suksessfaktorene sykepleierne beskrev, var variert praksis, god oppfølging i traineegruppene samt mulighet for medbestemmelse relatert til rullering mellom poster eller poliklinikker. Deltakerne opplevde også å få tillit fra kolleger og ledere, slik denne deltakeren beskrev:

«Mitt inntrykk er at traineesykepleierne er ønsket på avdelingen de er på, og har tillit fra ledere tidlig i perioden.»

Ved å delta i veiledning og samtaler opplevde deltakerne at de ble satset på, og at de fikk mulighet for utvikling. Ved å rullere mellom ulike sengeposter og poliklinikker fikk de dessuten større trygghet og innsikt til å kunne velge karriere videre.

Flere vurderte traineeprogrammet som verdifullt, da det ga dem betydelig informasjon om og opplæring i ulike sykepleiefaglige og organisatoriske temaer, som andre sykepleiere ikke fikk.

På den andre siden uttrykte deltakerne at det var stor variasjon i opplæringen de fikk ved de ulike sengepostene og poliklinikkene, slik en deltaker beskrev:

«Hadde best erfaring når jeg gikk sammen med en eller to faste sykepleiere. De periodene det var minst kontinuitet i veiledning, var selvfølgelig i periodene da studenter inntok avdelingene for å ha praksis.»

Deltakerne anbefalte at sengepostene og poliklinikkene hadde en god plan for oppfølging. De etterlyste mer målrettet oppfølging fra avdelingssykepleieren på den sengeposten eller poliklinikken sykepleieren var tilknyttet.

\section{Refleksjon og diskusjon}


Evalueringen viser at deltakerne opplevde å bli sett, hørt og verdsatt, og fikk mulighet til å utvikle seg som fagpersoner i løpet av traineeprogrammet. I denne sammenhengen var avdelingssykepleiernes engasjement viktig.

Forskning viser at nyutdannede sykepleiere som mottar veiledning fra mer erfarne sykepleiere, opplever mindre stress, bedre selvtillit i sykepleierrollen og fremskritt innen karriereutvikling og faglige ferdigheter (7).

\section{«Deltakerne opplevde å bli sett, hørt og verdsatt, og fikk mulighet til å utvikle seg som fagpersoner i løpet av traineeprogrammet.»}

I et traineeprogram kan avdelingssykepleieren bidra til traineesykepleierens faglige og karrieremessige utvikling ved å gi vedkommende mer oppmerksomhet og inkludere ham/henne i avdelingen, og som mentor ved utfordrende sykepleieoppgaver (7).

Traineesykepleierne etterlyste bedre opplæring, særlig ved oppstarten på ny sengepost eller poliklinikk. De foreslo å forbedre traineeprogrammet med en mer strukturert oppfølging på hver enkelt sengepost. Dette forslaget ble tatt hensyn til. Blant annet ble det innført samtale med avdelingssykepleieren ved oppstarten, underveis og mot slutten av perioden.

Traineesykepleierne fremhevet at veiledningene og samtalene ga dem mulighet til og rom for refleksjon om faglige og etiske problemstillinger, noe som bidro til $\varnothing$ kt sykepleiefaglig kompetanse og erfaringsoverføring. Refleksjon krever avsatt tid, som er nødvendig for å kunne ha en kritisk granskende og svars $\varnothing$ kende holdning (8). 
Det at traineesykepleierne er i et kollegialt fellesskap med andre sykepleiere på sengepostene og poliklinikkene, reflekterer over praksis, utforsker handlingsalternativer og praktiserer erfaringsutveksling, er en forutsetning for at det kan skje læring på arbeidsplassen (8).

Sykepleierne beskrev at veiledningen bidro til nye perspektiver på utøvelsen av sykepleie, som også støttes av en begrepsanalyse om refleksjon (9). Refleksjon bidrar til nye perspektiver på egne ferdigheter, evner og praksis (9).

Deltakerne oppga også at støtten og oppfølgingen i veiledning og samtaler var viktig. Bie fant det samme i sin studie (8) og skriver at refleksjon sammen med andre kan være en kilde til følelsen av trygghet, tillit og støtte i samhandlingen mellom helsepersonell.

\section{Tidlig introduksjon kan styrke sykepleierens profesjonelle selvtillit}

Sykepleierne uttrykte at det å delta i

traineeprogrammet styrket deres sykepleiefaglige og organisatoriske kompetanse, noe som kan ha bidratt til større rolleforståelse og dypere innsikt i organiseringen av sykepleiepraksisen på sykehuset, i samsvar med funnene til Tashiro og medarbeidere (10).

\section{«Det å delta i traineeprogrammet styrket deres sykepleiefaglige og organisatoriske kompetanse.»}

Introduksjonsprogram til sykepleiere, i overgangen fra novise til ekspert, kan styrke deres profesjonelle selvtillit og kompetanse og forhindre opplevelsen av at de overlates til selv å måtte forme og tilpasse sin nye rolle (11).

Sykepleieres tro på egen evne til å utøve sykepleie øker de tre første årene etter utdanningen og påvirkes av kunnskap og ferdigheter som de tilegner seg gjennom daglig sykepleiepraksis og pasientomsorg (12). 
Det kan tenkes at et traineeprogram som introduseres tidlig i sykepleiekarrieren, og som gir sykepleieren variert praksis, mer kunnskap og bedre ferdigheter i tillegg til et utvidet organisatorisk nettverk, kan bidra til at sykepleieren opplever en styrket posisjon i klinikken, med lavere gjennomtrekk av ansatte som resultat.

\section{«Tillit» er et nøkkelbegrep}

Deltakerne i evalueringsprosjektet pekte på at det var viktig med tillit mellom lederen og traineesykepleieren og mellom traineesykepleieren og kollegene. Ordet «tillit» er et nøkkelbegrep i sosial kapital, som er egenskaper som setter organisasjonens medlemmer i stand til å løse kjerneoppgavene, og som omfatter samarbeid, tillit og rettferdighet (13).

Det at medarbeiderne møtes med tillit og opplever at lederen har tiltro til deres kompetanse, etterspør og lytter til deres erfaringer, kan bidra til økt kvalitet på det sykepleiefaglige arbeidet (13).

I sykehuset som organisasjon har lederne en viktig rolle som mentorer og gode brobyggere ved å bygge tillit og troverdighet til alle ansatte.

\section{Konklusjon og implikasjoner}

Vårt prosjekt har vist at å investere i og ta i bruk traineesykepleiernes sosiale kapital på de ulike sengepostene og poliklinikkene kan gi bedre arbeidsvilkår og kompetanse både underveis i og etter traineeprogrammet.

Evalueringen av traineeprogrammet ved SUS er verdifull for å kunne videreutvikle tilbudet om traineestillinger. Den har vist at programmet kan forbedres ved at deltakerne sikres relevant og tilstrekkelig opplæring i løpet av programmet.

Programmet har allerede vist seg drivverdig i form av $\varnothing$ konomisk gevinst og $\varnothing \mathrm{kt}$ rekruttering til spesialavdelinger og sykepleieledelse. Det stimulerer også til masterutdanning. 
Veiledningen som traineesykepleierne får i løpet av to år, gir nok veiledning til trinn 1 i Klinisk fagstige, som er et internt kompetanseløp på SUS. For mange er dette starten på godkjenning som klinisk spesialist $\mathrm{i}$ sykepleie i NSFs godkjenningsordning.

\section{Referanser}

1. Berge O, Hvitsand C. Interkommunalt traineeprogram som rekrutteringsstrategi. Evaluering av 12k trainee i Vestfold. B $\varnothing$ : Telemarksforskning; 2013. Rapport nr. 323 .

2. Syrstad B. Erfaringer fra et trainee-program for sykepleiere i postoperative og intensive avdelinger [masteroppgave]. Oslo: Universitetet i Oslo, Institutt for helse og samfunn; 2016.

3. Whitehead B, Owen P, Henshaw L, Beddingham E, Simmons M. Supporting newly qualified nurse transition: a case study in a UK hospital. Nurse Educ Today. 2016;36:58-63.

4. Schroeder E. Evaluation of a fellowship program for nurse practitioner graduates in an academic environment. Florida: Jakcsonville University; 2016. Tilgjengelig fra: https://sigma.nursingrepository.org/bitstream/handle/10755/621179/SchroederEricaDNP.pdf? sequence $=3$ (nedlastet 10.08.2021).

5. $\quad$ Hinnerson KM, Wijk H. Betydelser av ett 1-årigt traineeprogram för praktisk färdighetsutveckling av nyutexaminerade sjuksköterskor inom barn- och ungdomssjukvård. Vård i Norden. 2008;28(1):41-4.

6. Helse Stavanger. Traineestillinger på SUS: sykepleiere med kunnskap, kontakter og fast jobb etter to år. Stavanger: Stavanger universitetssjukehus; 2017. Tilgjengelig fra: https://helse-stavanger.no/omoss/nyheter/traineestillinger-pa-sus-sykepleiere-medkunnskap-kontakter-og-fast-jobb-etter-to-ar (nedlastet 25.06.2021). 
7. Gazaway SB, Schumacher AM, Anderson L.

Mentoring to retain newly hired nurses. Nurs Manage. 2016;47(8):9-13.

8. Bie K. Refleksjon. Sykepleierens vei til klokskap. Oslo: Universitetsforlaget; 2020.

9. Tashiro J, Shimpuku Y, Naruse K, Maftuhah, Matsutani M. Concept analysis of reflection in nursing professional development. Jpn J Nurs Sci.

2013;10(2):170-9.

10. Speight C, Firnhaber G, Scott ES, Wei H.

Strategies to promote the professional transition of new graduate nurse practitioners: a systematic review. Nurs Forum. 2019;54(4):557-64.

11. Edwards D, Hawker C, Carrier J, Rees C. A systematic review of the effectiveness of strategies and interventions to improve the transition from student to newly qualified nurse. Int J Nurs Stud. 2015;52(7):1254-68.

12. Ehrenberg A, Gustavsson P, Wallin L, Boström AM, Rudman A. New graduate nurses' developmental trajectories for capability beliefs concerning core competencies for healthcare professionals: a national cohort study on patient-centered care, teamwork, and evidence-based practice. Worldviews Evid Based Nurs. 2016;13(6):454-62.

13. Vevatne K. Ledelse for sykepleiere - likeverd i relasjoner. 1. utg. Bergen: Fagbokforlaget; 2020. 